GSI Journals Serie A: Advancements in Tourism, Recreation and Sports Sciences (GSI Dergileri Seri A: Turizm, Rekreasyon ve Spor Bilimlerindeki Gelişmeler) ATRSS 2022, 5 (1): 85-93 - Research Article - Received.: 17.12.2021 - Published.: 22.02.2022

\title{
A Preliminary Assessment on the Accessibility of Urban Green Spaces: The Case of Bursa, Yildirım*
}

Gül SAYAN ATANUR, Bursa Technical University, Faculty of Forestry, Department of Landscape Architecture, gul.atanur@btu.edu.tr, Bursa, Turkey, ORCID: 0000-0001-7240-8839

Merve ERSOY MİRICI, Bursa Technical University, Faculty of Forestry, Department of Landscape Architecture, merve.mirici@btu.edu.tr, ORCID: 0000-0002-8610-6169

Nazlı Deniz ERSÖZ, Bursa Technical University, Faculty of Forestry, Department of Landscape Architecture, nazli.ersoz@btu.edu.tr, ORCID: 0000-0002-3851-2859

Kübra HAN, Bursa Technical University, Faculty of Forestry, Department of Landscape Architecture, kubrahan.kbh@gmail.com, ORCID: 0000-0002-7980-0523

\begin{abstract}
The irreversible reduction of urban open and green spaces has increased the environmental problems in cities on the one hand, and negatively affected the quality of urban life on the other. Bringing the city and nature together again has become a common concern for the environment-city-focused professions. Green infrastructure systems, one of the approaches put forward with these concerns by increasing the capacity of ecosystem services. Yildirm, which was examined in this study, is one of the main districts of Bursa in terms of population and area. The lack of green space is intense in Yildirim. Within the scope of the study, the pedestrian accessibility of green areas in selected 15 neighborhoods around Bursa Technical University was carried out. The results of the study show that while green areas are accessible, the neighborhoods have a critical situation in terms of the amount of green space per person. It is aimed that the results obtained will constitute a base for studies that will evaluate green areas as an infrastructure element.
\end{abstract}

Keywords: Bursa-Yildirm, green infrastructure, ecosystem services, urban, accessibility

*This study is not included in the study group that requires TR Index ethics committee approval. 
Atanur Sayan G., Ersoy Mirici, M., Ersöz, N. D. \& Han K. (2022). A Preliminary Assessment on the Accessibility of Urban Green Spaces: The Case of Bursa, Yildırım. GSI Journals Serie A: Advancements in Tourism, Recreation and Sports Sciences (ATRSS), 5 (1): $85-93$

\section{Introduction}

Urban green spaces in the urban landscape have a significant role in balancing the deteriorated relationship between human and nature as a result of rapid urbanization and increasing the quality of life. Urban and neighborhood parks, children's playgrounds, sports fields, urban forests, botanical parks, zoos, regional parks, protected areas and national parks are various types of urban green spaces in or around the urban areas. Urban green space provides a green pattern for the cities. This pattern contributes to the city as an ecological component, increasing the ecosystem service capacity while offering a social amenity. When the pattern and integration of green spaces is altered through land cover changes, it leads to habitat fragmentation, loss of biodiversity, and the decrease of ecosystem services in urban areas (Xiu, Ignatieva \& Konijnendijk, van den Bosch, 2016).

Urban green spaces, which are public spaces open to the whole city-dwellers to benefit, are not only used in terms of ecosystem services, but also to provide social interaction between the people (Chang et al, 2017). They are freely used by all people of the city without any discrimination and economic constraints. Additionally, open and green spaces enable the users to provide relationships with their immediate surroundings and increase the sense of belonging and ownership to the city. These social functions Urban green spaces are significant to increase the quality of life in cities and provide the right to the city. Although equality is fundamental while planning and designing green spaces in urban areas, the existence of green spaces in the neighborhoods, districts and city and the percentage to benefit from them are not always equal. The level of quality of life in relation to the open and green spaces and the benefits the citydwellers provide differs in terms of socio-economic standards of residential areas in the city. The contribution of urban green spaces to improve the quality of life is especially important in irregularly developed housing areas located on the urban fringes where the low-income groups settle (Ersoy, 2016).

Accessibility is one of the physical factors that directly or indirectly affects urban green space planning. In addition to the adequacy of the public parks throughout the city, the easy access of the city-dwellers to these areas is also a very important issue. In today's world, where private vehicle ownership is increasing gradually, it is of great importance to access the parks both on foot and by using public transportation vehicles and main transportation networks, and to offer these areas to the service of citizens of all income levels. One of the factors affecting the recreational value of the parks and determining the frequency of use is their accessibility. Various studies conducted in Sweden show that the majority of the people want to access the park on foot, and they can regularly use the parks that are 3-5 minutes away from their homes/workplaces (Thompson, 2002). Environments that have accessible green spaces are necessary to the promotion of healthy physical activity (Foster et al., 2004). A study by Takono (2002) shows a significant relationship between the longevity of urban senior citizens and the availability of green areas within close walking distance.

When considering accessibility of a park, firstly, it is important to have a comfortable and easy access to the parking area from outside, as well as to easily perceive the legibility of the park area. Access to the parking areas should be provided by various types of transportation and the users such as pedestrians, private cars, bicycles or buses. The second important issue regarding accessibility is; how the park and its surroundings are related. Ease of access is related to the patterns of connecting roads within the park (Baljon, 1992). Li et al. (2005) found that the decision to walk is significantly affected by neighborhood character. Areas of high employment and high housing density, with more street intersections and greater amounts of green and open space, are likely to increase urban mobility through walking.

It is seen that the accessibility of open and green spaces, which contributes to increase the quality of urban spaces, is a significant parameter while planning and designing the urban green pattern. In this context, urban green spaces of European cities have increased by $38 \%$ over the last 25 years, with $44 \%$ of Europe's urban population currently living within 300 meters of a public park (EU, 2019). 
The motivation of the study was to question the accessibility of urban green spaces of 15 neighborhoods in Bursa-Yıldirım district. In this sense, the aim of this study is to determine the accessibility of the urban green space in the neighborhoods of Yildırım district. The 250 and 500-meter walking distances were used as the accessibility scale. Results showed that most of the neighborhood's green spaces are within walking distance. However, the amount of green urban green space per person is very low. It is aimed to use these outputs in the next stages of the research for urban green spaces and green infrastructure planning and design processes.

\section{Material and Methods}

\subsection{Material}

Yildırım district, which was determined as the study area for this article, has a high population density. Compared to other central districts of Bursa, Yildirım is the most problematic district where the green areas have the least percentage with 188,476 ha urban green spaces (Atanur \& Ersoy Mirici, 2020). Yıldırım district, where the population is increasing gradually due to intense migration, is Uludag in the south, Kestel and Gursu in the east, and Gursu in the west. It is surrounded by agricultural fields in Osmangazi and its north. Throughout the metropolitan planning region of Bursa (Sayan Atanur \& Ersoy Mirici, 2019) Yildırım has the lowest urban green spaces per person. The main reason why the study area was chosen as Yıldırım district, where Bursa Technical University campus is located, is that the urban green spaces are scarce and unevenly distributed in the district, which has a high rate of construction. The scarcity of open and green spaces indicates the need to develop an open and green space strategy.

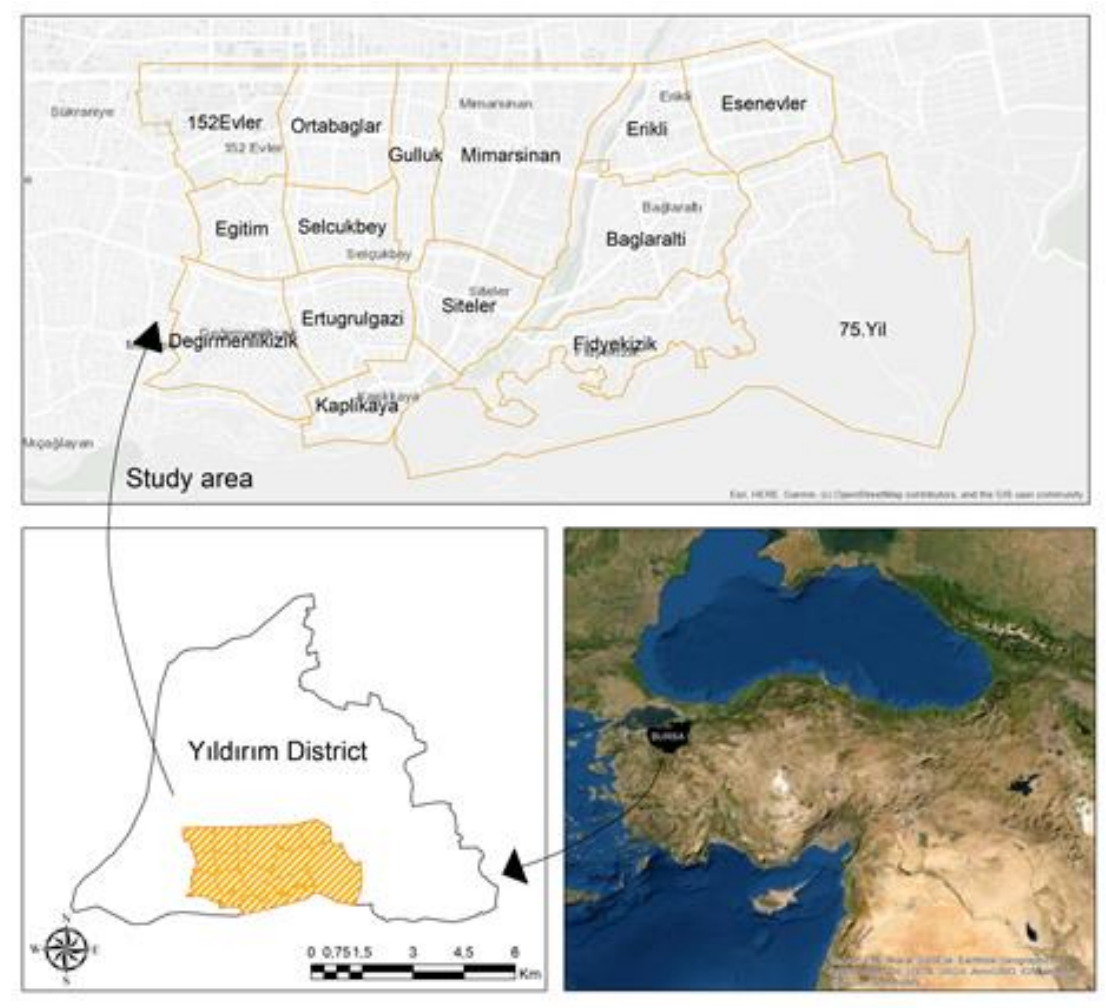

Figure 1. Study area

Within the scope of the study, 15 neighborhoods of Y1ldırım district surrounding Bursa Technical University were examined. The study area has been shown in Fig. 1 that it is covered by 15 neighborhoods respectively 152 Evler, 75. Yıl, Baglaraltı, Degirmenlikızık, Egitim, Erikli, Ertugrulgazi, Esenevler, Fidyekızık, Güllük, Kaplıkaya, Mimarsinan, Ortabaglar, Selçukbey and Siteler and there is totally 10,680 $\mathrm{km} 2$. This neighborhood has important in future projection because it is adjacent and close to Bursa 
Technical University Mimar Sinan Campus. It has possible urban transformation potential in future due to student density.

\subsection{Methods}

In the study; (i) worldview-2 satellite view; (ii) 1/1000 zoning plan (Bursa Metropolitan Municipality, 2021), (iii) park information obtained from the municipality were used. In the first stage of the study, the satellite image dated September 2020 was classified as object-based. The land cover map, which is classified precisely with a resolution of $50 \mathrm{~cm}$, is defined in 7 classes as road, building, green area (urban green space), agriculture, bare ground, concrete ground and stream. This study has been focused on urban green spaces, for this reason it has been integrated the land use classification, master plan map and municipality park excel information. In the second stage of the study, since it is not possible to distinguish urban green areas as public, private or forest in this classification, the park information obtained from the municipality was transferred to the GIS environment. The main purpose of classifying the land cover is to obtain the spatial dynamics of the study area as up-to-date and accurately. Parks were integrated into the land use classes obtained with high precision to provide a more accurate result. In the third stage of the study, the accessibility of parks located in 15 neighborhoods in Yıldırım district was examined through buffer analysis. The buffer analysis was used to inquire walkable accessibility in this study. The urban green space where is under a minimum of $5000 \mathrm{~m} 2$ in the neighborhood unit is characterized as a small park and the service radius of them is between 250-500 meter (m) (Lawson, Boud-Bovy, 1973; Tümer 1976; Gallion, Eisner, 1986, Keeble, 1986; Nyhuus Thoren, 1992; Aydemir et al. 1993; Ersoy, 1994; Aydemir, 2004; Unal et. al, 2016). This reason it has been used $250 \mathrm{~m}$. and $500 \mathrm{~m}$ buffer zones due to almost all green space (parks) are being under $5000 \mathrm{~m}^{2}$.

\section{Findings \& Results}

\subsection{Urban Green Space in Land Use and Master Plan}

Yildırım district is a problematic area for planning and design approaches, with its insufficient area for the dense population. Therefore, in order to manage these issues, spatial characteristics of the Yildirim should be investigated deeply. With this study, the evaluation has been studied for 15 neighborhoods in Yıldırım district, which are located around Bursa Technical University Mimar Sinan Campus. Firstly, the total urban green spaces of the districts were determined. In order to obtain this data, the $50 \mathrm{~cm}$ resolution worldview-2 satellite image dated September 2020 was classified with object-based classification. The land use classification and the spatial distribution of these uses are shown in figure 2 below.
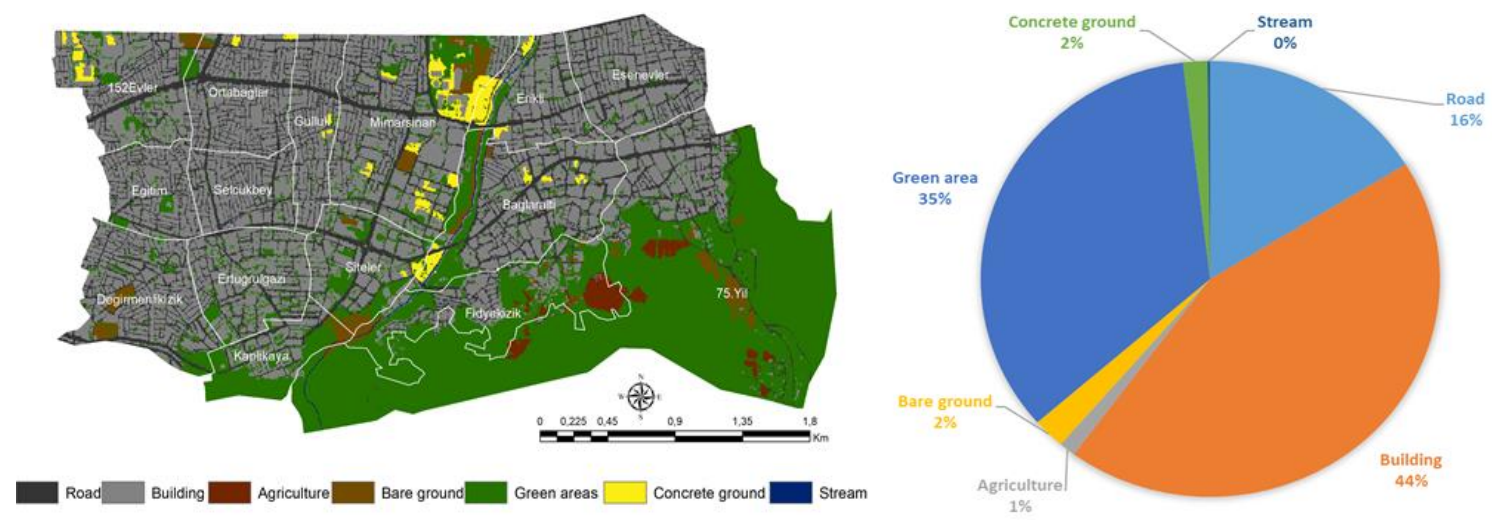

Figure 2. Land use map (2020) and distribution of land use class area.

In the study area, Worldview-2 satellite image is classified with object-based classification. By this classification, it is possible to see that the green areas are spread over a wide area of approximately 369 ha., $35 \%$ in the areal distribution. However, the size of the urban green space examined through spatial information systems was obtained approximately 37 ha. The southeastern part of the study area is a forest 
of Uludag skirt. This reason it has extensive green spaces but inside the urban place there are very limited and heterogeneous green spaces. In the 15 neighborhoods focused on in the first stage of the study, it was determined that the green area presence decreased to $5 \%$ within the scope of the size of the public green spaces. Therefore, the slopes of Uludag Mountain, located in the south of Yildirım district, make it difficult to interpret the green areas in the land use map. The main motivation of this study is the existence of public green spaces in Yıldirım district and access to green spaces in the axis of urban equality paradigm. In this context, the spatial distribution of public open and green spaces are discussed within the scope of the first stage. Both the support of remote sensing and geographic information systems and the cooperation with the municipality in the field have provided more accurate results. At the second stage of the study, park information obtained from the Yıldırım municipality is transferred into the GIS program. Public parks are determined for 15 neighborhoods. Buffers are added to the parks at 250 and 500 m radius. According to the buffer analysis, the parks in the selected 15 neighborhoods are accessible.
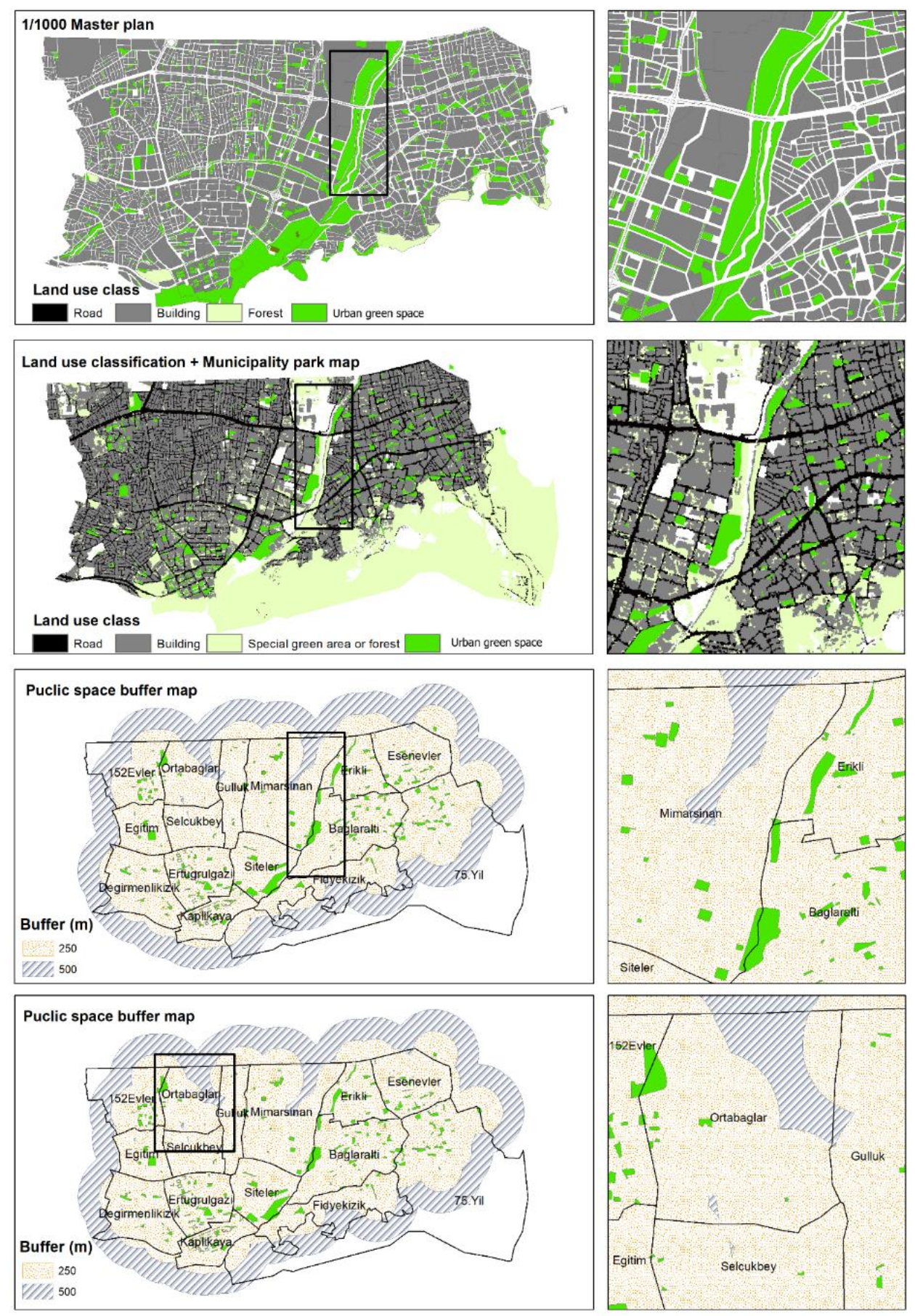

Figure 3. Urban green space buffer map 
Atanur Sayan G., Ersoy Mirici, M., Ersöz, N. D. \& Han K. (2022). A Preliminary Assessment on the Accessibility of Urban Green Spaces: The Case of Bursa, Yıldırım. GSI Journals Serie A: Advancements in Tourism, Recreation and Sports Sciences (ATRSS), 5 (1): $85-93$

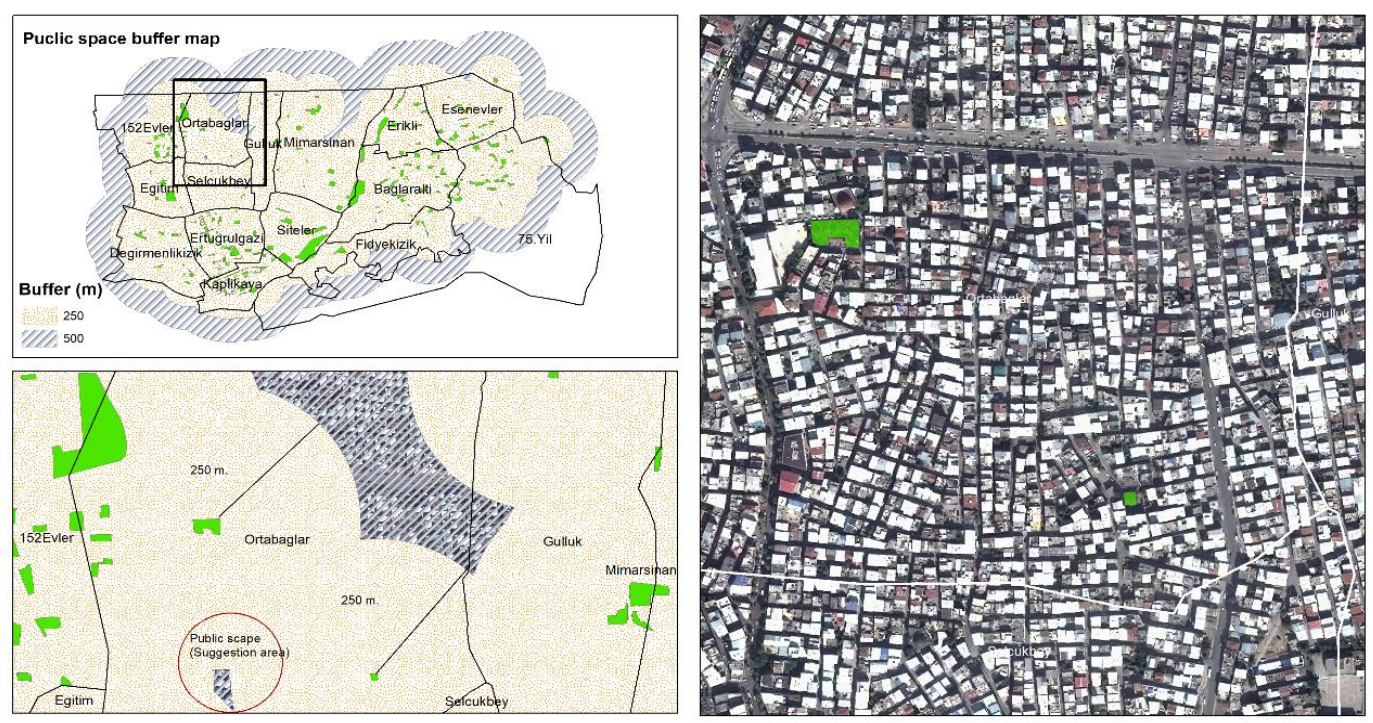

Figure 4. Ortabaglar neighborhood urban green spaces with buffers.

Table 1. Neighborhoods and urban green spaces for per person

\begin{tabular}{cccccc}
\hline $\begin{array}{c}\text { Neighborhood } \\
\text { name }\end{array}$ & $\begin{array}{c}\text { Neigborhood } \\
\left.\text { area } \mathbf{( m}^{2}\right)\end{array}$ & $\begin{array}{c}\text { Urban green } \\
\text { space (UGS) } \\
\text { area }\left(\mathbf{m}^{2}\right)\end{array}$ & $\begin{array}{c}\text { Neigborhood } \\
\text { area/UGS (\%) }\end{array}$ & $\begin{array}{c}\text { Neigborhood } \\
\text { population }\end{array}$ & $\begin{array}{c}\text { Urban green } \\
\text { space per } \\
\left.\text { person } \mathbf{( m}^{\mathbf{2}}\right)\end{array}$ \\
\hline 152 Evler & 587189,243 & 30059,28 & $\% 5,11$ & 9132 & 3,292 \\
\hline 75. Yil & 3025715,552 & 30199,53 & $\% 0,99$ & 10190 & 2,964 \\
\hline Baglaralt1 & 850880,088 & 40118,95 & $\% 4,71$ & 18555 & 2,162 \\
\hline Degirmenlikizik & 625368,731 & 16896,59 & $\% 2,70$ & 16250 & 1,040 \\
\hline Egitim & 333309,887 & 14245,55 & $\% 4,27$ & 11474 & 1,242 \\
\hline Erikli & 417098,790 & 33792,78 & $\% 8,10$ & 12836 & 2,633 \\
\hline Ertugrulgazi & 480623,882 & 36425,84 & $\% 7,57$ & 9144 & 3,984 \\
\hline Esenevler & 561858,447 & 16021,41 & $\% 2,85$ & 18138 & 0,883 \\
\hline Fidyekizik & 683956,465 & 9625,07 & $\% 1,40$ & 5167 & 1,863 \\
\hline Gulluk & 348571,064 & 6531,5 & $\% 1,87$ & 9892 & 0,660 \\
\hline Kaplikaya & 329708,857 & 31795,13 & $\% 9,64$ & 3782 & 8,407 \\
\hline Mimarsinan & 1124007,844 & 51421,34 & $\% 4,57$ & 12398 & 4,148 \\
\hline Ortabaglar & 515799,039 & 1313,74 & $\% 0,25$ & 15965 & 0,082 \\
\hline Selcukbey & 342382,260 & 1021,39 & $\% 0,29$ & 11560 & 0,088 \\
\hline Siteler & 453370,740 & 49677,15 & $\% 10,95$ & 5208 & 9,539
\end{tabular}

\section{Discussion}

In order to fulfill their functions, urban green spaces should be accessible, positioned in accordance with their purpose, and within walking distance of the neighborhood and sub-scales (Aydemir et al. 2004). According to buffer analysis this study area has no accessibility problem but equality of the green spaces is questionable. The urban green space in nearly every neighborhood in the study area is accessible since the areas of the neighborhoods in Yıldırım district are very small with an intense population. 
Consequently, the problem is not accessibility but equality and rights, especially living and urban green spaces per person It has been detected that there are site-specific problems for open and green spaces in Yildırım district. In particular, the major difference between the perception of space in the third dimension and the planning approaches made in two dimensions in the upper scale is detected in this study. Table 1 has been shown urban green space per person for each neighborhood. According to table 1. urban green spaces per person in this study area have a variable between 0,082 $\mathrm{m} 2 /$ person and 9,53 $\mathrm{m} 2 /$ person. The most problematic neighborhood in the study area has been determined as the Ortabaglar which have urban green space per person is 0,082 (it even not $1 \mathrm{~m} 2$ ). For this reason, we focused on Ortabağlar urban green space and neighborhood microform urban pattern. (Figure 4). Ortabaglar neighborhood is an unplanned settlement with an area of $0.52 \mathrm{~km} 2$. The 2020 population of this neighborhood is 15965 . There are two public green spaces in Ortabaglar neighborhood as Ortanca park and Ortabaglar park. Ortanca park is $1155 \mathrm{~m} 2$ and Ortabaglar park is $158 \mathrm{~m} 2$. A buffer zone was studied for these parks in Ortabaglar. Although no accessibility problems were detected for Ortabaglar, the amount of green space per person is $0.082 \mathrm{~m} 2$. This situation shows that while there is no problem of accessibility to open and green spaces in the neighborhoods of Yıldirım district, such as Ortabaglar, the amount of space per person is quite low.

In Turkey, the green space standart was $4 \mathrm{~m} 2 /$ person in 1993 (Duyguluer, 1989). This standard was upper $7 \mathrm{~m} /$ person and $10 \mathrm{~m} 2 /$ person respectively 1972 and 2000. The town planning system in Turkey exhibits a holistic and top-down characteristic. In Turkey, the Planning Law no. 3194 has the nature of a basic law with regard to planning, and is the most comprehensive law related to making spatial plans in terms of procedures and principles, planning powers, and preparation, approval and implementation of plans (Planning Law, Offical Gazette, 18749 (09/05/1985), Law No. 3194). At the drafting and approval stage of zoning plans in Turkey, the basic law is the Planning Law no. 3194 (Dede \& Sekeroğlu 2020; Ersoy Mirici, 2021). Currently the Ministry of the Environment and Urbanisation was founded, the Spatial Plans Formation Regulation was prepared in 2011. According to Spatial Plans Formation Regulation, urban green space should be $10 \mathrm{~m} 2 /$ person. Siteler neighborhood have around standard in Yildirım. The others of neighborhoods except Siteler are considerably under $10 \mathrm{~m} 2$ /person as urban green space standart. The neighborhoods which have the lowest urban green space respectively are Ortabaglar, Selçukbey, Güllük, Esenevler and Degirmenlikızık. Causing it most important major factors are migration and unplanned building. Inded urban green space has been determined to be approximately $10 \mathrm{~m} 2 /$ person in Siteler and Kaplıkaya which are planned neighborhoods.

\section{Conclusion and Suggestions}

The effects of irregular and unplanned urbanization, which is the result of population growth in cities, industrialization and technological developments and the decrease in green space in cities reveal the importance of the green spaces (Discoli \& Martini, 2012). Therefore, especially for emerging and developing countries, a dramatic increase in urbanization is inevitable. It is predicted that approximately $70 \%$ of the world's population will live in cities by 2050 (Cheng, 2021; IPCC, 2014). Considering that a large part of the world's population lives in cities and the unplanned building density is, it is clearly seen how important the need for green space is.

With the decrease in green areas, it is obvious that the existing green systems should be integrated into the urban fabric in a planned way. In the neighborhoods of Yildırım district, which were analyzed within the scope of this study, the accessibility of the parks was examined. The study was structured in different phases, and the first stage of the study was carried out for 15 neighborhoods around the Bursa Technical University Mimar Sinan Campus. Most of the urban green spaces have 250 and 500-meter accessibility distance. However, accessibility of the open and green spaces is not an individual criteria to determine the green space adequacy. The size and quality of the open and green spaces should also be taken into account. The amount of green space per person Turkish zoning legislation is $10 \mathrm{~m} 2 /$ person currently. In this context, Yıldırım district, which consists mostly of unplanned areas, has a green area amount far 
Atanur Sayan G., Ersoy Mirici, M., Ersöz, N. D. \& Han K. (2022). A Preliminary Assessment on the Accessibility of Urban Green Spaces: The Case of Bursa, Yıldırım. GSI Journals Serie A: Advancements in Tourism, Recreation and Sports Sciences (ATRSS), 5 (1): $85-93$

below the Turkish zoning legislation. To benefit from open and green spaces equally and fairly is the right to the city. Policies should be developed for the revision of private and public living spaces for Yildirım District, where the city right for equal open and green spaces is problematic. One of the main purposes of these revisions should be enhancing the green area per person.

\section{Acknowledgments and Info}

The authors thank Bursa Technical University Scientific Research Projects Unit for their support.

Support Info: This study is carried out within the scope of the Scientific Research Project numbered 211N015 in Bursa Technical University.

Ethical Approval: In the article, the authors declare that they comply with national and international research and publication ethics. In case of detection of a contrary situation, GSI Journals Serie A: Advancements in Tourism Recreation and Sports Sciences Journal has no responsibility and all responsibility belongs to the article's authors.

Ethics Committee Approval: This study is not included in the study group that requires TR Index ethics committee approval.

Conflict of Interest: There is no conflict of interest or gain in the article.

Contribution Rate of Researchers: The study was prepared with the contribution of four authors.

Contribution rates: 1 . Author $=30 \%, 2$. Author $=30 \%$, 3. Author $=30 \%$, 4. Author $=10 \%$

\section{References}

Atanur, G. \& Ersoy Mirici, M. (2020). Yeşil altyapı kavramı çerçevesinde Bursa Merkez planlama bölgesi yeşil alan sisteminin belirlenmesi. Peyzaj Araştırmaları ve Uygulamaları Dergisi, 2(1), 11-18.

Aydemir, S. N. \& Ökten, A. M. Öksüz, 1993. Konut alanları donatı standartları DPT 91.11.002.2, KTÜ, Trabzon, Cilt1, 120-243.

Aydemir, Ş., Erkonak Aydemir, S., Şen Beyazlı, D., Ökten, N., Öksüz, A. M., Sancar, C., Özyaba, M. \& Aydın Türk, Y. (2004). Kentsel alanların planlaması ve tasarımı. Akademi Kitabevi, Trabzon.

Baljon, L. (1992). Designing Parks: an examination of contemporary approaches to design in landscape architecture, based on a comparative design analysis of entries for the Concours International: Parc de la Villette, Paris, 1982-3. Wageningen University and Research.

Bursa Metropolitan Municipality, (2021). Bursa Yıldırım District 1/1000 Zoning Plan.

Chang, Z., Ronghua, X., Kaixuan, P., Bin, X., Yong, M., Yuan, R., Guofu, Y. \& Ying, G. (2017). Assessing the ecosystem services provided by urban green spaces along urban center-edge gradients. Nature, 7, 10.1038/s41598-017-11559-5.

Cheng, X., Van Damme, S. \& Uyttenhove, P. (2021). A review of empirical studies of cultural ecosystem services in urban green infrastructure. J. Environ. Manage. 293, 112895.

Dede, O. \& A Şekeroğlu. (2020). “Türkiye'de kent planlamada mekansal standartlar üzerine bir değerlendirme." Humanities Sciences (NWSAHS) $15 \quad$ (3): 96-110. https://doi.org/10.12739/NWSA.2020.15.3.4C0238.

Discoli, C. \& Martini, I. (2012). Unplanned urban growth and its effect on sustainability. Resource and environment, 2 (3), 107-115. 10.5923/j.re.20120203.05. 
Atanur Sayan G., Ersoy Mirici, M., Ersöz, N. D. \& Han K. (2022). A Preliminary Assessment on the Accessibility of Urban Green Spaces: The Case of Bursa, Yıldırım. GSI Journals Serie A: Advancements in Tourism, Recreation and Sports Sciences (ATRSS), 5 (1): $85-93$

Duyguluer, F. (1989). İmar mevzuatının Cumhuriyet Dönemi mimarlığına ve şehir plancılığına Etkileri, TBMM Kültür ve Sanat Yayınları, Ankara.

EU. (2019). The Future of Cities. Opportunities, Challenges and the Way Forward. Publications Office of the European Union. European Commission, Joint Research Center, Italy.

Ersoy, M. (1994). Kentsel Alanların Kullanım Normları, ODTÜ Mimarlık Fakültesi Yayınları, Ankara.

Ersoy, M. (2016). Kentsel Planlama Ansiklopedik Sözlük. İkinci Bas. Ankara: Ninova Yayıncılık.

Ersoy Mirici, M. (2021). Spatial planning, landscape and climate justice, Turkey, A. Altuntaş (Eds). In Planning, Design and Management in Landscape Architecture. IKSAD Publishing House.

Esri, Maxar, GeoEye, Earthstar Geographic, CNES/Airbus DS, USDA, USGS, AeroGRID, IGN, GIS User Community, (2021). World satellite map.

IPCC. Urban Areas. in Climate Change 2014: Impacts, Adaptation, and Vulnerability. Part A: Global and Sectoral Aspects. Contribution of Working Group II to the Fifth Assessment Report of the Intergovernmental Panel on Climate Change. Cambridge University.

Foster C., Hillsdon M. \& Thorogood M. (2004). Environmental perceptions and walking in English adults, J EpidemiolCommunity Health 2004; 58:924-928. doi: 10.1136/jech.2003.014068

Gallion, A. Eisner, S. (1986). The urban pattern, Van Nostrard Renhold, New York.

Lawson, F. M. \& Boud-Bovy, M. (1997). Tourism and recreation development, Architectural Press, London.

Li F., Fisher K J., Brownson R. \& Bosworth M. (2005). Multilevel modelling of built environment characteristics related to neighbourhood walking activity in older adults, Jech Online $2005 \mathrm{~J}$. Epidemiol. Community Health 2005;59;558-564

Keeble, L. (1986). Town planning made plane, Construction Press, England.

Nyhuus, S. \& Thoren, A. H. (1992). Green structure planning on Norvegian cities, UN7. Conferance on Urban and Regional Research: Urban Ecology, Ankara, 269-288.

Sayan Atanur, G. \& Ersoy Mirici, M. (2019). Yeşil altyapı çerçevesinde Bursa Merkez planlama bölgesi yeşil alan sisteminin belirlenmesi. Türkiye Peyzajları 3. Ulusal Konferansı. Antalya.

Unal, M., Uslu, C., \& Cilek, A. (2016). GIS-based accessibility analysis for neighbourhood parks: The case of Cukurova district. Journal of Digital Landscape Architecture, 1, 46-56.

Takano T, Nakamura K. \& Watanabe M. (2002). Urban residential environments and senior citizens' longevity in megacity areas: the importance of walkable green spaces, J Epidemiol Community Health 2002;56:913-918

Thompson, C. W. (2002). Urban open space in the 21st century. Landscape and urban planning, 60(2), 5972.

Tümer, S. (1976). Rekreatif alan ve tesisleri ölçütler, Turizm ve Tanıtma Bakanlığı Planlama Dairesi Başkanlı̆̆ı, Ankara.

Woldview-2, (2021). Yıldırım Municipality, TÜRKSAT Worlview-2 Satellite Image. (Date information: September 2021)

Xiu, N., Ignatieva, M. \& Konijnendijk van den Bosch, C. (2016). Planning and design of urban green networks in Stockholm. In Proceedings of the Fábos Conference on Landscape and Greenway Planning (Vol. 5, No. 1, p. 4).

Y1ldırım Municipality, (2021). Neighborhood boundary map. 